\title{
THIAMINE DEFICIENCY IN EXTREMELY PREMATURE NEWBORNS
}

Introduction. The critical state of extremely premature newborns is accompanied by significant oxidative stress, which leads to an increase in anaerobic metabolism; impaired oxygen utilization in mitochondrial oxidation may occur due to thiamine deficiency.

The aim of the study - to learn the thiamine status of extremely premature newborns in the neonatal period follow-up.

Research Methods. The study involved 55 of premature newborns with birth weight less than $1000 \mathrm{~g}$ and 35 healthy full-term newborns. The indicated children's blood tests were made in the first day of life and at the end of the neonatal period. The lactate and magnesium were determined by colorimetric method; the pyruvate content was determined enzymatically; the concentration of vitamin B1 was studied using a fluorimeter.

Results and Discussion. In the first days of life, all premature infants have a significantly lower level of thiamine in the blood than the normal one, with the low limit of the norm of mature infants, due to the greatest intensity of adaptive reactions and the redistribution of nutrients in fasting. The deficiency of thiamine of extremely premature infants is accompanied by hypomagnesemia. The defining factor of thiamine deficiency of premature infants is morphofunctional immaturity. Deficiency of thiamine of premature infants is correlated with hyperlactatemia throughout the neonatal period. The metabolic features of an organism of a newborn with an extremely low birth weight reflect hypoxic disturbances (increased lactate and pyruvate level, changes in their ratio), which indicates the activation of glycolysis. The highest level of pyruvate was observed in premature infants in the first day of life and significantly exceeded the reference values with subsequent decrease during the first month of life, but remained beyond the norm, resulting in the development of secondary acidosis and persistent decrease in aerobic metabolism. Thiamine deficiency contributes to the pathogenesis of suppression of the pyruvate-dehydrogenase complex, bypassing pyruvate towards lactate overproduction and the development of metabolic acidosis.

Conclusion. Deficiency of thiamine in premature newborns may lead to a deeper critical condition.

KEY WORDS: hypoxia; premature newborns; lactate; pyruvate; vitamin $\mathrm{B}_{1}$.

INTRODUCTION. Particular attention is paid to the study of the health of premature newborns with birth body weight less than $1000 \mathrm{~g}$. Current scientific advances in the field of perinatal technology have significantly improved the survival rate of newborns with an extremely low birth weight $[1,2]$. The birth rate of babies with a low birth weight (less than $1000 \mathrm{~g}$ ) is $0.2 \%$, with an extremely low birth weight (from 1000 to $1500 \mathrm{~g}$ ) it is equal to $0.8 \%$ [3]. However, it is this category of children that determines the high mortality and the formation of pathologies in the children's population, which leads to disability [4]. Energy metabolism and extremely premature newborns weight gain are undoubtedly related to the conditions of care and the prevention of energy costs. Also, the complications that formed during the neonatal period (patent ductus arteriosus), which worsens the oxygen state of the body, are of great importance. It is hypoxia that is the

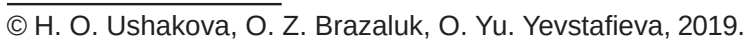

leading pathogenetic factor; as a result, the mitochondria of brain cells in the process of oxidative phosphorylation can not effectively use energy substrates, which leads to the accumulation of lactate and the development of acidosis - one of the factors that damage neurons.

The critical condition of premature babies may be associated with the risk of thiamine deficiency (TD), a coenzyme of enzymes of mitochondrial glucose oxidation [5]. Thiamine pyrophosphate (TPP), the active form of thiamine, is a coenzyme of pyruvate decarboxylase and $\alpha$-ketoglutarate dehydrogenase complexes, as well as transketolase. The first two enzymes are involved in the metabolism of carbohydrates, transketolase functions in the pentophosphase cycle. TPP is synthesized mainly in the brain and liver tissues, the reaction occurs with the participation of $\mathrm{Mg}^{2+}$ ions. Thiamine deficiency also leads to lactic acidosis, slowing down the oxidative decarboxylation of 
pyruvate, accumulation of intermediate metabolites and a decrease in ATP synthesis [6]. That is why TD in premature babies can significantly worsen the symptoms of an existing critical condition. As a rule, clinicians do not diagnose TD as the cause of metabolic acidosis in extremely premature newborns. Currently, there is no clear evidence that all premature newborns have TD and a risk of developing thiamine-deficient complications. However, in the works of some authors, TD is associated with a worsening condition of patients in critical condition. $[7,8]$, whereas in other studies this relationship was not found $[9,10]$. Such a discrepancy in the results can be explained both by different research designs and by different methods for measuring the blood thiamine concentration. Therefore, the study of thiamine status of extremely premature newborns is important for evaluating the results of intensive therapy [11].

RESEARCH METHODS. The research was conducted on the basis of the Clinical Institution "Regional Children's Clinical Hospital" in 20172018. The main group involved 55 (22 boys and 33 girls) of premature newborns with extremely low body birth weight. The reference group involved 35 healthy full-term newborns (21 boys and 14 girls). The gestational age of the main group children ranged from 24 to 35 weeks, average birth weight $(891 \pm 79.2) \mathrm{g}$; in the reference group newborns with 38-39 weeks of gestation had an average weight of (2.045.94 \pm 290.19$) \mathrm{g}$. According to the gestational age the children of the main group were divided into 3 subgroups. The subgroup I: 13 newborns with 23-26 weeks of gestation, average birth weight (843.9 \pm 106.2$) \mathrm{g}$; the subgroup II: 24 newborns with 27-30 weeks of gestation, average birth weight (901.5 \pm 78.6$) \mathrm{g}$; the subgroup III: 13 newborns with 31-35 weeks of gestation, average birth weight $(902.36 \pm 77.54) \mathrm{g}$. Criteria for inclusion in the main group: birth weight up to $1000 \mathrm{~g}$, stabilization of the main vital functions before 1 month of life. Exclusion criteria: detected antenatal malformations, the presence of genetic diseases.

On the basis of the Department of Biochemistry and Medical Chemistry of Dnipro State Medical Academy the quantification of blood lactate, pyruvate, vitamin $\mathrm{B} 1$ and magnesium in children of the first day of life and after the newborn period was conducted. The serum concentration of lactate and magnesium were determined with the colorimetric method using Beckman Coulter reagents (USA), in $\mu \mathrm{mol} /$ /; the blood content of vitamin B1 was studied using Immundiagnostik reagents (Germany) on a microplate high-temperature fluorometer FluoDia T70 (England), in ng/ml. The blood content of pyruvate was studied with the enzymatic UV method using NPF-ABRIS reagents (Russia), in $\mu \mathrm{mol} / \mathrm{l}$. For statistical data processing, parametric (Student's) and nonparametric (Mann -Whitney test) criteria were used. The changes were considered reliable if $p \leq 0.05$ [7].

RESULTS AND DISCUSSION. Determination of the level of thiamine in blood of premature newborns with extremely low body weight established a reliable increase of $8.4-8.9 \%$ in all subgroups of the main group during the first month of life and a slightly lower increase in new-borns of the control group - by $7.8 \%$. On the first day of life, the blood thiamine content in the main group babies was significantly lower than the reference value, probably due to enhanced catabolism, the creation of conditions for gluconeogenesis, the redistribution of nutrients and energy during fasting. On the first day, the thiamine content in the reference group babies was observed at the lower limit of normal. There is a close inverse correlation between the blood thiamine level and the gestational age of children in subgroups I and II during the entire neonatal period ( $r=-0.75$ to $-0.81 ; p \leq 0.05$ ); In the subgroup III, this connection was less explicit $(r=-0.56$ and $r=-0.67 ; p \leq 0.05)$. There was no statistically significant connection found between the level of thiamine and gestation in the reference group. Between the level of thiamine and body birth weight during the neonatal period, a close inverse correlation was observed only in extremely premature new-borns, between 23 and 26 weeks of gestation ( $r=-0.59$ and $r=-0.63 ; p \leq 0.05)$; in other subgroups and in full-term newborns no close correlation was found. Based on these data, it can be assumed that morphofunctional immaturity is a major pathogenetic factor in preterm newborns thiamine deficiency. In all subgroups of the main group, the serum lactate level, which significantly exceeded the norm (2.77 times in subgroup I, 2.44 times in subgroup II and 1.8 times in subgroup III) in the first day of life, decreased by $7.5-9.1 \%$ during the month, which can be explained by the intensive care effectiveness and compensatory mechanisms activation (Table). In all subgroups, there was a close inverse correlation between the content of lactate and gestation ( $r=-0.92$ to $-0.46 ; p \leq 0.05)$, which is confirmed in other studies [11]. At the same time, there are no close correlations between the lactate level and body birth weight in all subgroups, which can be explained by the low variation ( $8.8 \%)$ of weight in the main group. Newborn hyperlactatemia indicates glycolysis activation and is a sign of dismal prognosis [12]. In healthy, full-term babies, the lactate level during the entire neonatal period corresponded to normal values with a decrease in the end by $8.9 \%$, largely due to the restoration of 
Table - The content of thiamine, lactate, pyruvate and magnesium in the blood of premature and healthy children $(\mathrm{M} \pm \mathrm{m})$

\begin{tabular}{|c|c|c|c|c|c|c|c|c|}
\hline \multirow[t]{2}{*}{ Indicator } & \multicolumn{2}{|c|}{$\begin{array}{l}\text { Subgroup I }(\mathrm{n}=13) \\
23-26 \text { weeks } \\
\text { of gestation }\end{array}$} & \multicolumn{2}{|c|}{$\begin{array}{c}\text { Subgroup II }(n=24) \\
27-30 \text { weeks } \\
\text { of gestation }\end{array}$} & \multicolumn{2}{|c|}{$\begin{array}{c}\text { Subgroup III }(n=13) \\
31-35 \text { weeks } \\
\text { of gestation }\end{array}$} & \multicolumn{2}{|c|}{$\begin{array}{c}\text { Reference group }(n=35) \\
37-38 \text { weeks } \\
\text { of gestation }\end{array}$} \\
\hline & $\begin{array}{l}1^{\text {st }} \text { day } \\
\text { of life }\end{array}$ & $\begin{array}{l}1 \text { month } \\
\text { of age }\end{array}$ & $\begin{array}{l}1^{\text {st }} \text { day } \\
\text { of life }\end{array}$ & $\begin{array}{l}1 \text { month } \\
\text { of age }\end{array}$ & $\begin{array}{l}1^{\text {st }} \text { day } \\
\text { of life }\end{array}$ & $\begin{array}{l}1 \text { month } \\
\text { of age }\end{array}$ & $\begin{array}{l}1^{\text {st }} \text { day } \\
\text { of life }\end{array}$ & $\begin{array}{l}1 \text { month } \\
\text { of age }\end{array}$ \\
\hline $\begin{array}{l}\text { Thiamine, } \\
\mathrm{ng} / \mathrm{ml}\end{array}$ & $\begin{array}{c}11.5 \pm \\
1.45\end{array}$ & $\begin{array}{c}13.29 \pm \\
1.68^{\star *}\end{array}$ & $\begin{array}{c}14.96 \pm \\
1.9 *\end{array}$ & $\begin{array}{c}16.85 \pm \\
1.6^{\star \star}\end{array}$ & $\begin{array}{c}15.79 \pm \\
2.49^{*}\end{array}$ & $\begin{array}{l}18.63 \pm \\
2.21^{\star \star}\end{array}$ & $\begin{array}{c}30.86 \pm \\
5.67\end{array}$ & $\begin{array}{c}39.35 \pm \\
2.87\end{array}$ \\
\hline $\begin{array}{l}\text { Lactate, } \\
\mu \mathrm{mol} / /\end{array}$ & $\begin{array}{l}6.77 \pm \\
0.63\end{array}$ & $\begin{array}{l}5.65 \pm \\
0.69 * *\end{array}$ & $\begin{array}{l}5.93 \pm \\
0.21 *\end{array}$ & $\begin{array}{l}5.4 \pm \\
0.2^{* *}\end{array}$ & $\begin{array}{l}5.62 \pm \\
0.079 *\end{array}$ & $\begin{array}{c}4.22 \pm \\
0.106^{\star *}\end{array}$ & $\begin{array}{l}2.22 \pm \\
0.016\end{array}$ & $\begin{array}{l}1.98 \pm \\
0.167\end{array}$ \\
\hline $\begin{array}{l}\text { Pyruvate, } \\
\mu \mathrm{mol} / /\end{array}$ & $\begin{array}{l}0.65 \pm \\
0.076\end{array}$ & $\begin{array}{l}0.39 \pm \\
0.12^{\star \star}\end{array}$ & $\begin{array}{l}0.59 \pm \\
0.09 * 8\end{array}$ & $\begin{array}{l}0.43 \pm \\
0.07^{\star \star}\end{array}$ & $\begin{array}{l}0.47 \pm \\
0.078^{\star}\end{array}$ & $\begin{array}{l}0.25 \pm \\
0.07^{\star \star}\end{array}$ & $\begin{array}{l}0.15 \pm \\
0.021\end{array}$ & $\begin{array}{l}0.12 \pm \\
0.02\end{array}$ \\
\hline $\begin{array}{l}\text { Magnesium, } \\
\mu \mathrm{mol} / \mathrm{l}\end{array}$ & $\begin{array}{l}0.48 \pm \\
0.05\end{array}$ & $\begin{array}{c}0.65 \pm \\
0.036^{\star *}\end{array}$ & $\begin{array}{l}0.52 \pm \\
0.38^{*}\end{array}$ & $\begin{array}{c}0.72 \pm \\
0.086^{\star *}\end{array}$ & $\begin{array}{l}0.53 \pm \\
0.048^{\star}\end{array}$ & $\begin{array}{c}0.81 \pm \\
0.081^{\star *}\end{array}$ & $\begin{array}{l}0.75 \pm \\
0.075\end{array}$ & $\begin{array}{c}0.8 \pm \\
0.054 \\
\end{array}$ \\
\hline
\end{tabular}

Note. ${ }^{*}$ - Statistical difference compared to subgroup I $(p \leq 0.5) ;{ }^{*}$ - Statistical difference compared to reference group $(p \leq 0.01)$.

the protective-compensatory forces of the body. In all subgroups of the main group, TD correlated with hyperlactatemia during the entire neonatal period (Figure), with lower coefficients in the subgroup III $(r=-0.92$ to $-0.56 ; p \leq 0.05)$. Based on these data, it can be assumed that TD affects the development of acidosis and tissue hypoxia. The level of pyruvate on the first day of life in children of subgroups I, II, III of the main group significantly exceeded normal values (by 4.1; 3.6; 2.9 times, respectively); the accumulation of pyruvate due to slowing down of the transformation to acetyl-CoA leads to the se- condary acidosis development. At the end of the first month of life, the level of pyruvate decreased significantly in all subgroups of the main group: by $40.1 \%$ in subgroup I, by $27 \%$ in subgroup II and by $46 \%$ in subgroup III, but reached normal levels in none of them. The study showed that between the thiamine content and the level of pyruvate during the neonatal period, there is a close inverse correlation ( $r=-0.94$ to $-0.66 ; p \leq 0.05)$ in subgroup I and subgroup II, but less expressed in subgroup III $(r=-0.56$ and $r=-0.49 ; p \leq 0.05)$. The ratio of lactate/ pyruvate in the first days of life in premature new-
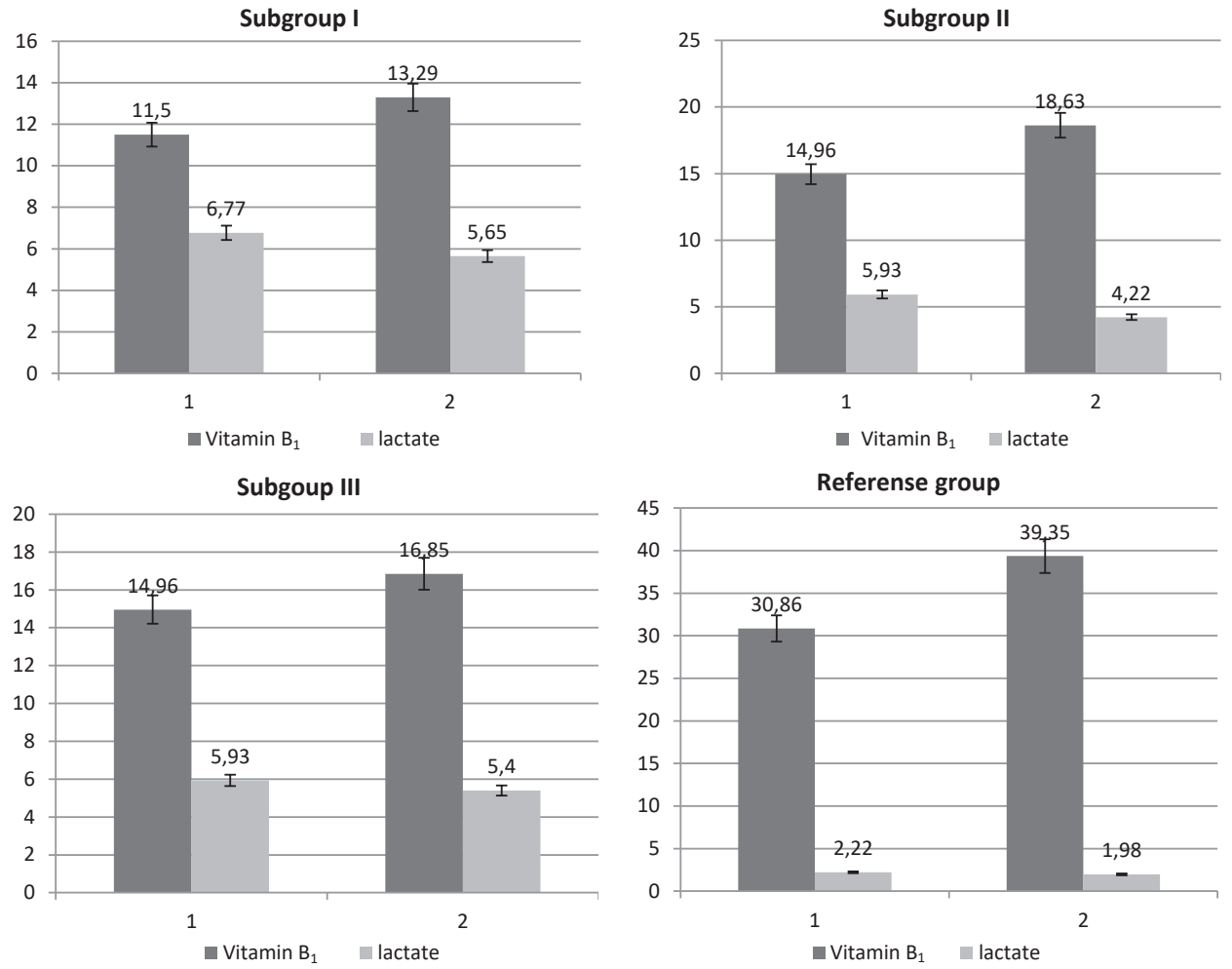

Fig. The content of thiamine and lactate in the blood of premature and healthy children in neonatal period follow-up. Note. $1-1^{\text {st }}$ day of life; $2-$ end of neonatal period. 
borns of subgroups I and II when the levels of lactate and pyruvate were elevated was within normal (10.4 and 10.5), with a subsequent increase to 14.4 and 12.5 at the end of the neonatal period, which is the result of lactate decrease and a more drastic pyruvate drop; thus, the lactate/pyruvate ratio cannot reveal an imbalance of these metabolites in children of low gestational age (23-30 weeks). In children of the subgroup III, who were relatively more gestationally mature, the lactate/ pyruvate ratio was close to the full-term value: from 12.0 and 14.8 at the beginning of the first month of life and to 14.8 and 16.2 at the end respectively; a possible explanation for this data is to gradually compensate for metabolic disorders. Based on the data obtained, it can be assumed that under conditions of thiamine insufficiency in extremely premature newborns, they have thiamine deficiency, under which pyruvate is not involved in the Krebs cycle and is converted into lactate, which is a significant contribution to the formation of metabolic acidosis. Low levels of magnesium in the blood serum on the first day of life were found in children of all subgroups of the main group; during the month, its level in the extremely premature new-borns of subgroup I grew by $26.2 \%$ but did not reach the reference values, and in children of the subgroup II and III, with high gestational age, grew by $27.8 \%$ and $34.5 \%$ respectively, was within the normal. In healthy, full-term new-borns, normal magnesium levels were observed on the first day of life; during the month, this value rose by another $6.3 \%$. In all the subgroups of the main group, in the first days of life, a close direct relationship was found between the blood thiamine content and the serum magnesium level ( $r=0.72 ; 0.76 ; 0.82 ; p \leq 0.05$, respectively). At the end of the neonatal period, a close correlation between levels of thiamine and magnesium remained only in the newborns of subgroup I with the lowest gestational age $(r=0.76 ; p \leq 0.05)$. In healthy newborns, no statistically significant connections was found between the content of thiamine and magnesium.

CONCLUSIONS. 1. A study of lactate concentrations in premature newborns with extremely low birth weight is a screening method for diagnosing the degree of hypoxia; hyperlactatemia is a sign of dismal prognosis.

2. Hyperlakatemia has a heterogeneous nature: the determination of pyruvate level and the calculation of lactate/pyruvate ratio should be used to assess the degree of tissue hypoxia in premature newborns.

3. With intensive care in extremely premature newborns thiamine deficiency, not diagnosed as the cause of lactic acidosis, can result in worsening of an existing critical condition; subject to adequate correction, a gradual increase in the level of thiamine in the blood reduces the risk of developing thiaminedeficient complications.

4. To assess the thiamine status of children in critical conditions, standardization of thiamine determination methods is necessary.
LIST OF LITERATURE

1. Александрович Ю. С. Интенсивная терапия новорожденных / Ю. С. Александрович, К. В. Пшениснов. - СПб. : Изд-во Н-Л, 2013. - 672 с.

2. Неонатология. Национальное руководство / под ред. Н. Н. Володина. - М. : ГЭОТАР-Медиа, 2008. 749 c.

3. Oxygenationof the newborn: a molecular approach / O. D. Saugstad, Y. Sejersted, R. Solberg [et al.] // Neonatology. -2012. - 101, No. 4. - P. 315-325.

4. Clark R. H. Extrauterine growth restriction remains a serious problem in prematurely born neonates / R. H. Clark, P. Thomas, J. Peabody // Pediatrics. - 2003. 111. - P. 986-990.

5. Lima L. F. Low blood thiamine concentrations in children upon admission to the intensive care unit: risk factors and prognostic significance / L. F. Lima, H. P. Leite, J. A. Taddei // Am. J. Clin. Nutr. - 2011. - 93. - P. 57-61.

6. Gubler C. J. Thiamine. In: Handbook of Vitamins / C. J. Gubler. - Ed. L. J. Machlin. New York, Marcel Dekke Publ. - 1991. - P. 233-281.
7. Cruickshank A. M. Thiamine deficiency in the critically ill / A. M. Cruickshank, A. B. Telfer, A. Shenkin // Intens. Care Med. - 1988. - 14. - P. 384-387.

8. Lonsdale D. A review of the biochemistry, metabolism and clinical benefits of thiamine and its derivatives / D. Lonsdale // Evid. Based Complement. Alternat. Med. - 2006. - 3. - P. 49-59.

9. Thiamine deficiency in critically ill patients with sepsis / M. W. Donnino, E. Camey, M. N. Cocchi [et al.] // J. Crit. Care. - 2010. - 25. - P. 576-581.

10. Serum thiamine concentration and oxidative stress as predictors of mortality in patients with septic shock / N. A. Costa, A. L. Gut, M. de Souza Dorna [et al.] // J. Crit. Care. - 2014. - 29. - P. 249-252.

11. Десрицит тиамина и его коррекция при критических состояниях / В. В. Ломиворотов, М.Н.Дерягин, М. Н. Абубакиров [и др.] // Вестн. анестезиологии и реаниматологии. - 2017. - 14, № 5. - С. 73-81.

12. Шабалов Н. П. Неонатология / Н. П. Шабалов. - М. : МЕДпресс-информ, 2004. - 608 с. 


\section{REFERENCES}

1. Aleksandrovich, Yu.S., \& Pshenisnov, K.V. (2013). Intensivnaya terapiya novorozhdennykh [Intensive therapy of newborns]. Saint-Petersburg, N-L Publ. [in Russian].

2. Volodin, N.N. (Ed.). (2008). Neonatologiya. Natsionalnoye rukovodstvo. [Neonatology. National Guidelines]. Moscow: GEOTAR-Media [in Russian].

3. Saugstad, O.D., Sejersted, Y., \& Solberg, R. (2012). Oxygenation of the newborn: a molecular approach. Neonatology, 101 (4), 315-325.

4. Clark, R.H., Thomas, P., \& Peabody, J. (2003). Extrauterine growth restriction remains a serious problem in prematurely born neonates. Pediatrics, 111, 986-990.

5. Lima, L.F., Leite, H.P., \& Taddei, J.A. (2011). Low blood thiamine concentrations in children upon admission to the intensive care unit: risk factors and prognostic significance. Am. J. Clin. Nutr., 93, 57-61.

6. Gubler, C.J. (1991). Thiamine. In: Handbook of Vitamins. Machlin, L.J. (Ed.). New York, Marcel Dekke Publ.

7. Cruickshank, A.M., Telfer, A.B., \& Shenkin, A. (1988). Thiamine deficiency in the critically ill. Intens. Care Med., 14, 384-387.
8. Lonsdale, D. (2006). A review of the biochemistry, metabolism and clinical benefits of thiamine and its derivatives. Evid. Based. Complement Alternat. Med., 3, 49-59.

9. Donnino, M.W., Camey, E., \& Cocchi, M.N. (2010). Thiamine deficiency in critically ill patients with sepsis. J. Crit. Care, 25, 576-581.

10. Costa, N.A., Gut, A.L., \& de Souza Dorna M. (2014). Serum thiamine concentration and oxidative stress as predictors of mortality in patients with septic shock. J. Crit. Care, 29, 249-252.

11. Lomivorotov, V.V., Deryagin, M.N., Abubakirov, M.N., Fominskiy, E.V., \& Nepomnyaschikh, V.A. (2017). Deficyt tiamina i ego lechenye $v$ kriticheskikh sostoyaniyakh [Thiamine deficiency and its management in critical states]. Vestnik anesteziologii i reanimatologii Messenger of Anesthesiology and Resuscitation, 14 (5), 73-81 [in Russian].

12. Shabalov, N.P. (2006). Neonatologiya. [Neonatology]. MEDpress-inform [in Russian].

\section{ДЕФІЦИТ ТІАМІНУ В ГЛИБОКОНЕДОНОШЕНИХ ДІТЕЙ}

\section{Резюме}

Вступ. Критичний стан глибоконедоношених дітей супроводжується значним оксидативним стресом, що призводить до підвищення анаеробного метаболізму; порушення утилізації кисню при мітохондріальному окисненні буває внаслідок недостатності тіаміну.

Мета дослідження - вивчити тіаміновий статус у глибоконедоношених дітей у динаміці неонатального періоду.

Методи дослідження. У дослідженні взяли участь 55 недоношених дітей з масою тіла при народженні менше 1000 г та 35 здорових доношених новонароджених. У цих дітей досліджували кров, отриману на периу добу життя та наприкінці неонатального періоду. Вміст лактату та магнію визначали колориметричним методом, вміст пірувату - ензиматично, концентрацію вітаміну $B_{1}$ - за допомогою фрлуориметра.

Результати й обговорення. На першу добу життя вміст тіаміну в крові всіх недоношених дітей виявився значно нижчим за норму, а в доношених малюків перебував на нижній межі норми, ймовірно, внаслідок найбільшого напруження адаптивних реакцій та перерозподілу поживних речовин при голодуванні. У глибоконедоношених дітей дефріцит тіаміну супроводжувався гіпомагніємією. Визначальним чинником десріциту тіаміну в недоношених малюків була морфофрункціональна незрілість. Дефіцит тіаміну в них корелював з гіперлактатемією протягом усього неонатального періоду. Найвищий рівень пірувату спостерігали в недоношених дітей на першу добу життя. Він значно переважав референсні значення з наступним зменшенням протягом першого місяця життя, але залишився поза межами норми, що призвело до розвитку вторинного ацидозу та стійкого зниження аеробного метаболізму. Метаболічні особливості організму новонародженого з екстремально малою масою тіла відображають гіпоксичні порушення (підвищення рівня лактату та пірувату, зміну їх співвідношення), що свідчить про активацію гліколізу. Десріцит тіаміну спричиняє пригнічення піруват-дегідрогеназного комплексу та розвиток метаболічного ацидозу.

Висновок. Десріцит тіаміну в недоношених новонароджених може призвести до поглиблення критичного стану.

КЛЮчОВІ СЛОВА: гіпоксія; недоношені діти; лактат; магній; піруват; вітамін В. $_{1}$ 
Г. А. Ушакова ${ }^{1}$, А. 3. Бразалук², О. Ю. Евстафьева² ДНЕПРОВСКИЙ НАЦИОНАЛЬНЫЙ УНИВЕРСИТЕТ ИМЕНИ ОЛЕСЯ ГОНЧАРА ДНЕПРОПЕТРОВСКАЯ МЕДИЦИНСКАЯ АКАДЕМИЯ²

\section{ДЕФИЦИТ ТИАМИНА У ГЛУБОКОНЕДОНОШЕННЫХ ДЕТЕЙ}

\section{Резюме}

Вступление. Критическое состояние глубоконедоношенных детей сопровождается значительным оксидативным стрессом, который приводит к повышению анаэробного метаболизма; нарушение утилизации кислорода при митохондриальном окислении бывает вследствие недостаточности тиамина.

Цель исследования - изучить тиаминовый статус у глубоконедоношенных детей в динамике неонатального периода.

Методы исследования. В исследовании приняли участие 55 недоношенных детей с массой тела при рождении менее 1000 г и 35 здоровых доношенных новорожденных. У этих детей исследовали кровь, полученную в первые сутки жизни и в конце неонатального периода. Содержание лактата и магния определяли колориметрическим методом, содержание пирувата - энзиматически, концентрацию витамина $B_{1}$ - с помощью фрлуориметра.

Результаты и обсуждение. На первые сутки жизни содержание тиамина в крови всех недоношенных детей оказалось значительно ниже нормы, а у доношенных малышей находилось на нижней границе нормы, вероятно, вследствие наибольшего напряжения адаптивных реакций и перераспределения питательных веществ при голодании. У глубоконедоношенных детей дефрицит тиамина сопровождался гипомагниемией. Ведущим фрактором дефицита тиамина у недоношенных малышей была морфрофрунциональная незрелость. Дефицит тиамина у них кореллировал с гиперлактатемией на протяжении всего неонатального периода. Наивысший уровень пирувата наблюдали у недоношенных детей на первые сутки жизни. Он значительно превышал референсные значения с последующим уменьшением на протяжении первого месяца жизни, но остался вне нормальных значений, что привело к развитию вторичного ацидоза и стойкому снижению аэробного метаболизма. Метаболические особенности организма новорожденного с экстремально низкой массой тела отражают гипоксические нарушения (повышение уровня лактата и пирувата, изменение их соотношения), что свидетельствует об активации гликолиза. Дефицит тиамина вызывает угнетение пируват-дегидрогеназного комплекса и развитие метаболического ацидоза.

Вывод. Дефицит тиамина у недоношенных новорожденных может привести к углублению критического состояния.

КЛЮЧЕВЫЕ СЛОВА: гипоксия; недоношенные дети; лактат; магний; пируват; витамин В.

Received 16.04.19

Address for correspondence: O. Yu. Yevstafieva, Institute of Pediatrics, Obstetrics and Gynaecology named after Academician O. M. Lukyanova of the NAMS of Ukraine, Platon Mayborodi street, 8, Kyiv, 04050, Ukraine, e-mail: reines_gewissen@ukr.net. 